\title{
3. DIATOM BIOSTRATIGRAPHY OF LEG 108 SEDIMENTS: EASTERN TROPICAL ATLANTIC OCEAN ${ }^{1}$
}

\author{
Jack G. Baldauf ${ }^{2}$ and Edward M. Pokras ${ }^{3}$
}

\begin{abstract}
Diatoms are present in middle Eocene, upper Oligocene-lower Miocene, and Pliocene through Holocene sediments recovered during Leg 108 in the eastern tropical Atlantic Ocean. The diatom assemblage is dominated by species characteristic of a low-latitude, pelagic environment. A comparison of the diatom assemblage preserved at each site allows partial recognition of the 1985 diatom zonations of Barron, Fenner, and Baldauf. In addition, the abrupt occurrence of biosiliceous sediment suggests that present-day equatorial circulation and upwelling began during the late early Pliocene, approximately $3.5 \mathrm{Ma}$.
\end{abstract}

\section{INTRODUCTION}

Ocean Drilling Program (ODP) Leg 108 provided an opportunity to analyze Cretaceous and Eocene through Holocene sediments from the eastern tropical Atlantic Ocean. The 11 sites occupied during Leg 108 (Table 1 and Fig. 1) are situated in a variety of oceanographic environments and exhibit varying degrees of abundance and preservation of siliceous microfossils. For example, rare diatoms occur in the sediment recovered from Site 657 situated beneath the edge of a zone of high surface-water productivity, and few to common diatoms occur at Site 658 positioned near the center of the productivity cell.

Previous biostratigraphic studies of Paleogene through Quaternary diatoms for the low latitudes consist of studies primarily completed for the equatorial Pacific (Burckle, 1972, 1977, 1978; Burckle and Opdyke, 1977; Burckle and Trainer, 1979; Barron, 1980, 1983, 1985a; Harwood, 1982; Sancetta, 1983; Baldauf, 1985). By comparison, few studies have been completed for similar age sediments from the low-latitude Atlantic. A preliminary examination of Miocene through Holocene diatoms recovered at Deep Sea Drilling Project (DSDP) Site 332 was completed by Schrader (1977). Eocene through lower Miocene diatoms from the equatorial Atlantic regions have been studied by Fenner (1978, 1984, 1985).

The diatom assemblages preserved in Leg 108 sediments allow partial recognition of the low-latitude diatom zonations of Barron (1985a) and Fenner (1985), and the North Atlantic diatom zonation of Baldauf (1985). The Eocene diatom zones employed during this study follow the zonation defined by Fenner (1985) for the equatorial Pacific and Atlantic. The Oligocene through Miocene diatom zones follow the diatom zonation proposed by Barron (1985a, 1985b) for the equatorial Pacific; the Pliocene through Holocene zones follow the zonation defined by Baldauf (1985) for the North Atlantic (Figs. 2, 3, and 4).

The diatom assemblages observed in sediments recovered from Leg 108 consist of species typical of the low latitudes, with most age-diagnostic species for the late Pliocene and Quaternary present. However, several of the marker species either have a

\footnotetext{
${ }^{1}$ Ruddiman, W., Sarnthein, M., et al., 1989. Proc. ODP, Sci. Results, 108: College Station, TX (Ocean Drilling Program).

2 Ocean Drilling Program, 1000 Discovery Drive, College Station, TX 77840 .

${ }^{3}$ Lamont-Doherty Geological Observatory, Palisades, NY 10964.
}

sporadic stratigraphic occurrence or have stratigraphic ranges that are diachronous with their ranges in the equatorial Pacific and Atlantic oceans. In fact, several of the diatom species, such as Nitzschia reinholdii, have stratigraphic ranges more similar to those in the middle- and high-latitude North Atlantic than those in the low-latitude Pacific.

In addition, several species, such as Rhizosolenia praebergonii, Nitzschia jouseae, and Thalassiosira convexa, have sporadic stratigraphic occurrences that inhibit the determination of the exact placement of the zonal boundaries defined by these species. As a result, we are often required to follow Baldauf $(1984,1987)$ by replacing the Rhizosolenia praebergonii Zone and the uppermost portion of the Nitzschia jouseae Zone of Burckle (1977) with the Nitzschia marina Zone of Baldauf (1984; Figs. 2, 3, and 4). This latter zone is defined as the interval containing Nitzschia marina between the last occurrence (LO) of $N$. jouseae and the first occurrence (FO) of Pseudoeunotia doliolus. Baldauf (1987) divided this zone into two subzones based on the LO of $T$. convexa.

Although the chronostratigraphy used during Leg 108 follows that of Berggren et al. (1985a, 1985b), this chronology does not incorporate a diatom zonation. Therefore, a direct correlation of the FOs or LOs of diatom species to a magnetostratigraphic scale follows that of Barron (1985a, 1985b). Age estimates are based on stratigraphic data obtained from previously drilled DSDP/ODP sites in the low latitudes for those biostratigraphic events that lack direct ties with the geomagnetic polarity scale.

\section{METHODS}

Shipboard and subsequent shore-based sample preparation followed the method described in Baldauf (1984) with one exception. Because of the acidity of tap water on board JOIDES Resolution, decanting was generally not continued until a $\mathrm{pH}$ of 7 was reached. Strewn slides of acid-cleaned material were prepared on $22-\times 40-\mathrm{mm}$ cover glasses and mounted on $25-\times 75-\mathrm{mm}$ glass slides using Hyrax mounting medium.

Strewn slides were examined with a Zeiss compound microscope. At least 450 fields of view (0.5-mm diameter) were examined at $500 \times$, with species identifications confirmed when necessary at $1250 \times$. Species were considered abundant when two or more were present in one field of view at $500 \times$, common if one specimen was encountered in two fields of view, few if one specimen was observed in one horizontal traverse, and rare if less than one per traverse. Criteria for distinguishing whole from partial diatoms follow Schrader and Gersonde (1978).

Preservation was considered good if more than $95 \%$ of the diatoms were whole and valves showed virtually no signs of partial dissolu- 
Table 1. Latitude, longitude, and water depth of Sites 657 through 668.

\begin{tabular}{|c|c|c|}
\hline Site & Position & $\begin{array}{c}\text { Water } \\
\text { depth } \\
\text { (m) }\end{array}$ \\
\hline Site 657 & $21^{\circ} 19.89^{\prime} \mathrm{N}, 20^{\circ} 56.93^{\prime} \mathrm{W}$ & 4222 \\
\hline Site 658 & $20^{\circ} 44.95^{\prime} \mathrm{N}, 18^{\circ} 34.87^{\prime} \mathrm{W}$ & 2263 \\
\hline Site 659 & $18^{\circ} 04.63^{\prime} \mathrm{N}, 21^{\circ} 01.57^{\prime} \mathrm{W}$ & 3071 \\
\hline Site 660 & $10^{\circ} 00.809^{\prime} \mathrm{N}, 19^{\circ} 23.166^{\prime} \mathrm{W}$ & 4012 \\
\hline Site 661 & $9^{\circ} 26.81^{\prime} \mathrm{N}, 19^{\circ} 23.166^{\prime} \mathrm{W}$ & 4012 \\
\hline Site 662 & $1^{\circ} 23.41^{\prime} \mathrm{S}, 11^{\circ} 44.35^{\prime} \mathrm{W}$ & 3824.3 \\
\hline Site 663 & $1^{\circ} 11.87^{\prime} \mathrm{S}, 11^{\circ} 52.71^{\prime} \mathrm{W}$ & 3708.1 \\
\hline Site 664 & $0^{\circ} 06.44^{\prime} \mathrm{N}, 23^{\circ} 16.5^{\prime} \mathrm{W}$ & 3816.5 \\
\hline Site 665 & $2^{\circ} 57.07^{\prime} \mathrm{N}, 19^{\circ} 40.07^{\prime} \mathrm{W}$ & 4752.3 \\
\hline Site 666 & $3^{\circ} 29.84^{\prime} \mathrm{N}, 20^{\circ} 10.03^{\prime} \mathrm{W}$ & 4527.3 \\
\hline Site 667 & $4^{\circ} 34.15^{\prime} \mathrm{N}, 21^{\circ} 54.68^{\prime} \mathrm{W}$ & 3535.2 \\
\hline Site 668 & $4^{\circ} 46.12^{\prime} \mathrm{N}, 20^{\circ} 55.62^{\prime} \mathrm{W}$ & 2074 \\
\hline
\end{tabular}

tion, reprecipitation, or fracturing. Moderate preservation consisted of $30 \%-95 \%$ whole valves, with moderate breakage and slight dissolution, and some fragile specimens still complete. Also, girdle bands were generally intact. If less than $30 \%$ of the diatoms were whole, preservation was regarded as poor. Most diatoms showed extensive breakage, partial dissolution, and pitting. Delicate structures were generally not preserved, and fragile species and girdle bands were generally not intact. If no diatoms were encountered, the sample was recorded as barren.

\section{Biostratigraphy}

Figure 5 presents the Leg 108 diatom biostratigraphic results. Diatoms were observed in middle Eocene, upper Oligocene-lower Miocene, and Pliocene through Holocene sediments. The abundance and quality of frustule preservation varies at each site. With the exception of rare and sporadic occurrences, samples examined from Sites 659,661 , and 666 are generally barren of diatoms.

\section{SITE 657}

Site 657 (Table 1 and Fig. 1) was proposed as representative of the nonupwelling component of a series of sites (657-659) to examine the late Neogene history of the northern trade winds and upwelling off shore from Africa. Two holes were cored at this site: Hole $657 \mathrm{~A}$ recovered 16 advanced hydraulic piston corer (APC) and 3 extended core barrel (XCB) cores to $178.2 \mathrm{~m}$ below seafloor (mbsf), and Hole 657B recovered 19 APC cores to 166.1 mbsf.

With the exception of rare samples, diatoms are generally absent from the samples examined from each hole. The assemblage observed consists of a mixture of species characteristic of pelagic, coastal, and freshwater environments (with the latter two indicating eolian transport and/or redeposition). The low abundance of diatoms and the rare occurrence of biostratigraphic indicators limit the stratigraphic usefulness of diatoms at this site.

The occurrence of Pseudoeunotia doliolus without Nitzschia reinholdii in Samples 108-657A-3H-2, 42-44 cm, and 108-657A-3H-CC and in samples examined from Cores 108$657 \mathrm{~B}-1 \mathrm{H}$ through $-3 \mathrm{H}$ indicates placement of these samples into the late Pleistocene through Holocene Pseudoeunotia doliolus Zone of Burckle (1977). The rare and sporadic occurrence of diatoms stratigraphically below Cores $108-657 \mathrm{~A}-3 \mathrm{H}$ and 108-657B-3H prevents placement of the Pseudoeunotia doliolus/Nitzschia reinholdii zonal boundary and any other stratigraphic constraint of the sedimentary sequence.

\section{SITE 658}

Site 658 (Table 1 and Fig. 1) was proposed as representative of the "upwelling" component of a series of sites (657-659) to examine the late Neogene history of the northern trade winds and upwelling off shore from Africa. Three holes $(658 \mathrm{~A}-658 \mathrm{C})$ were cored at this site to depths of $157.9,163.8$, and 72.9 mbsf, respectively.

Diatoms are present in most samples examined from Holes $658 \mathrm{~A}$ and 658B. Although the diatom abundance and preservation varies from sample to sample, the diatom assemblage generally consists of few, poorly preserved specimens with occasional samples containing common to abundant, moderately well-preserved specimens. The diatom assemblage present is dominated by pelagic species indicative of high surfacewater productivity. Marine benthic diatoms, freshwater diatoms, and opal phytoliths (from eolian sources) were also observed throughout the recovered sequences.

Age-diagnostic species are present, but they often have sporadic ranges that result in tentative zonal assignments. The LO of Nitzschia reinholdii is assigned to Samples 108-658A$8 \mathrm{H}-\mathrm{CC}$ and 108-658B-8H-4, 92-94 cm. The occurrence of Pseudoeunotia doliolus stratigraphically above this LO allows Samples 108-658A-1H-CC to 108-658B-7H-CC and 108-658B$1 \mathrm{H}-\mathrm{CC}$ to $108-658 \mathrm{~B}-8 \mathrm{H}-1,92-94 \mathrm{~cm}$, to be placed in the Pseudoeunotia doliolus Zone of Burckle (1977).

The LO of $N$. reinholdii has been dated by Burckle (1977) for the tropical Pacific and has an estimated age of $0.65 \mathrm{Ma}$. In the middle- and high-latitude North Atlantic, this biostratigraphic event has an assigned age of $0.44 \mathrm{Ma}$ (Baldauf, 1987). The LO of $N$. reinholdii in Sample 108-658B-8H-4, 92-94 cm, is slightly above the LO of the calcareous nannofossil Pseudoumbilica lacunosa, which has an estimated age of $0.474 \mathrm{Ma}$ (Berggren, $1985 \mathrm{~b}$ ). This suggests that the LO of $N$. reinholdii in the eastern tropical Atlantic corresponds to the estimated age of its LO in the middle- and high-latitude Atlantic, and significantly postdates that in the equatorial Pacific.

Samples 108-658B-8H-4, 92-94 cm, through 108-658B$15 \mathrm{H}-1,62-64 \mathrm{~cm}$, are placed in the Nitzschia reinholdii Zone of Burckle (1977) based on the occurrence of $P$. doliolus with $N$, reinholdii. The FO of $P$. doliolus is tentatively placed in Sample 108-658B-15H-1, 62-64 cm; however, the occurrence of diatoms in this sample is extremely rare. Samples 108$658 \mathrm{~B}-14 \mathrm{H}-5,110-112 \mathrm{~cm}$, and 108-658B-15H-5, 110-112 cm, contain no age-diagnostic species limiting the stratigraphic interpretation. In Hole 658A, Pseudoeunotia doliolus first occurs in Sample 108-658A-14H-CC and allows the interval from Core $108-658 \mathrm{~A}-10 \mathrm{H}$ through $-14 \mathrm{H}$ to be assigned to the Nitzschia reinholdii Zone.

Samples 108-658A-15H-CC through 108-658C-23X-CC and Samples $108-658 \mathrm{~B}-15 \mathrm{H}-3,110-112 \mathrm{~cm}$, through the base of the hole (108-658B-18H-CC) are assigned to the Nitzschia marina Zone of Baldauf (1984). The occurrence of Thalassiosira convexa in Sample 108-658A-18H-CC and in Sample $108-658 \mathrm{~B}-18 \mathrm{H}-6,111-113 \mathrm{~cm}$, indicates that the LO of this species can be placed stratigraphically above these samples and suggests placement of these samples into Subzone A of the Nitzschia marina Zone of Baldauf (1987).

The occurrence of $N$. jouseae in Samples 108-658A24X-CC and 108-658A-26X-CC allows placement of these samples into the Nitzschia jouseae Zone of Baldauf (1984, 1987) and suggests that the base of the Nitzschia marina Zone approximates Sample 108-658A-24X-CC. Placement of the Nitzschia jouseae/Nitzschia marina zonal boundary is, however, tentative because of the sporadic and unreliable stratigraphic occurrence of Nitzschia jouseae at this site. The calcareous nannofossil stratigraphy (Manivit et al., this vol.) suggests that Sample $108-658 \mathrm{~A}-24 \mathrm{X}-\mathrm{CC}$ is slightly older $(2.9 \mathrm{Ma})$, indicating that this sample is indeed equivalent to the Nitzschia jouseae Zone, with the Nitzschia marina/Nitzschia jouseae zonal boundary occurring stratigraphically higher in the sequence. 


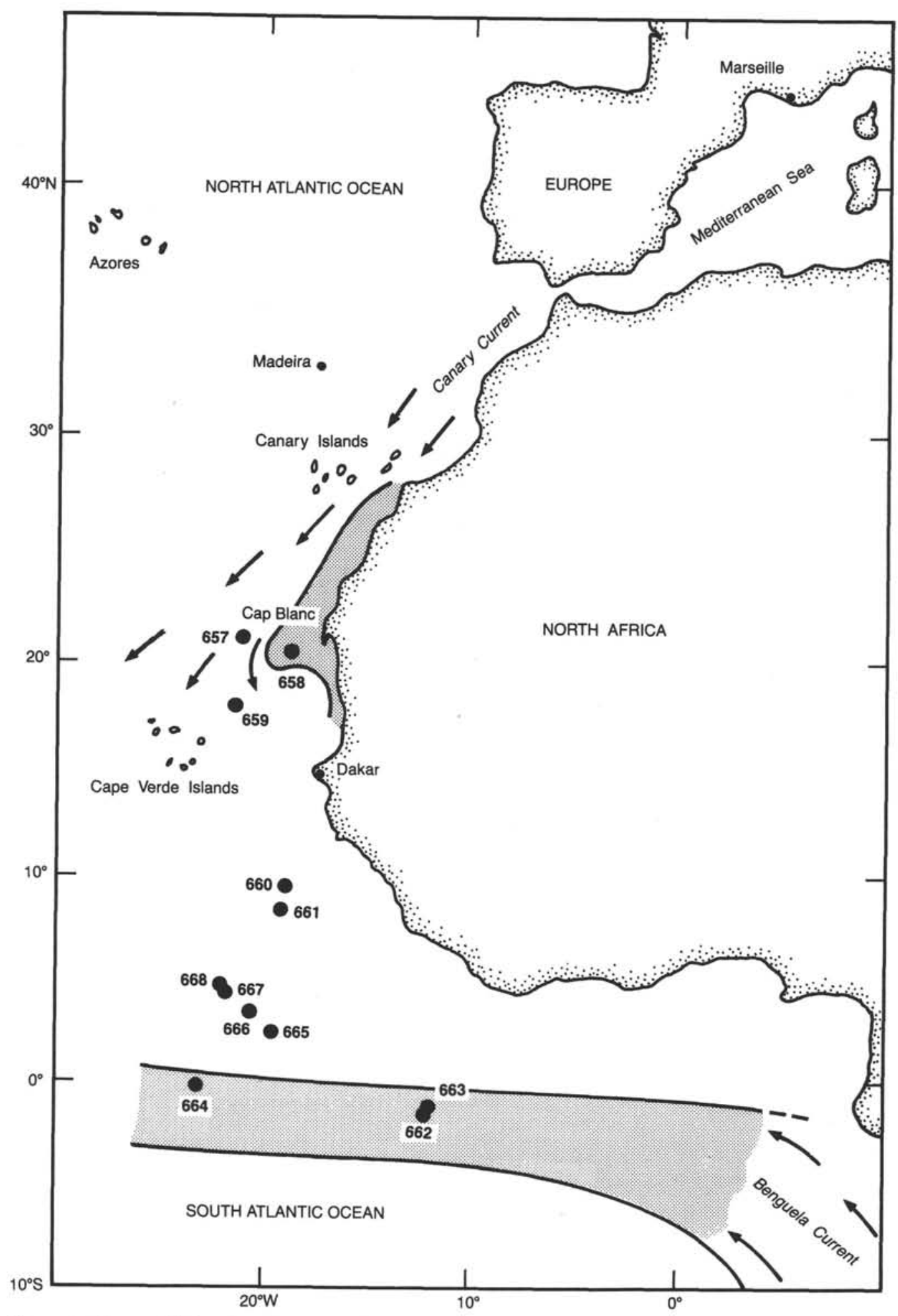

Figure 1. Geographic location of Leg 108 Sites 657-668. 


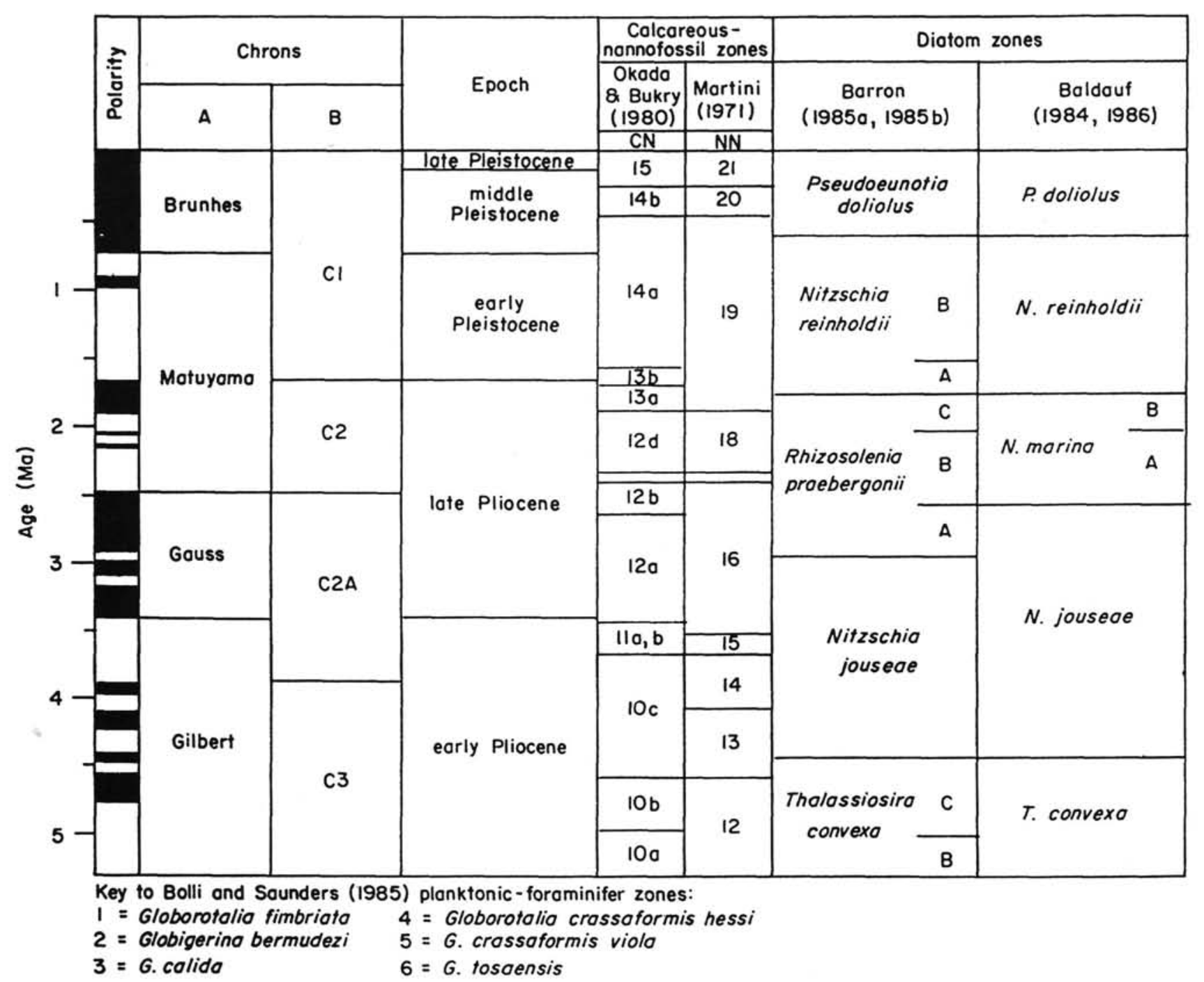

Figure 2. Pliocene to Holocene diatom zonation used during Leg 108. This zonation is a composite zonation of Burckle (1977), Barron (1985a), and Baldauf (1984, 1987).

The sporadic occurrence of Rhizosolenia praebergonii in Samples 108-658A-18H-CC, 108-658A-24X-CC through 108658A-26X-CC, 108-658B-14H-2, 110-112 cm, and 108-658A$16 \mathrm{H}-\mathrm{CC}$ allows placement of these samples into the Rhizosolenia praebergonii Zone of Burckle (1977). Although the sporadic occurrence of this species makes the use of this species unsuitable as a zonal marker, its occurrence suggests that these samples are equivalent to the upper portion of the Nitzschia jouseae through the lowermost portion of the Nitzschia reinholdii Zones. Non-age-diagnostic species were observed in samples examined from Cores 108-658A-27X through -33X.

\section{SITE 659}

Site 659 is located on the Cape Verde Plateau in the eastern Atlantic (Table 1 and Fig. 1). This site, like Sites 657 and 658 is situated to monitor surface-water productivity and to examine the late Neogene history of the northern trade winds and "upwelling" off shore from Africa. Three holes (659A-659C) were cored at this site penetrating 273.8, 202.1, and 196.0 mbsf, respectively.

Very few diatoms were observed in the samples examined from Site 659 . The diatom assemblage consists of neritic, fresh- water (eolian), and occasional pelagic species. Preservation was generally poor and no age-diagnostic species were observed.

\section{SITE 660}

Site 660 is situated near Kane Gap (Table 1 and Fig. 1) in order to monitor late Neogene bottom-current activity and deep-water stagnation. The two holes cored at this site $(660 \mathrm{~A}$ and $660 \mathrm{~B}$ ) penetrated 164.9 and $148.8 \mathrm{mbsf}$, respectively.

Diatoms were observed in middle Eocene and Quaternary sediments. The Quaternary assemblage consists of few, poorly preserved specimens. The assemblage contains warm and warm-temperate marine species with minor freshwater/ eolian components. The middle Eocene assemblage contains a poorly preserved assemblage of generally pelagic species. Although diversity is low, the assemblage is somewhat similar to that described from DSDP Site 354 (Fenner, 1978).

Few stratigraphically useful species are observed in the Quaternary and Eocene sequences. The occurrence of $P$. doliolus without $N$. reinholdii allows Cores $108-660 \mathrm{~A}-1 \mathrm{H}$ and 108-660B-1H to be placed in the Pseudoeunotia doliolus Zone of Burckle (1977). Samples examined from Core 108-660A-2H through Sample 108-660A-13H-7, 33-35 cm, and from Core 


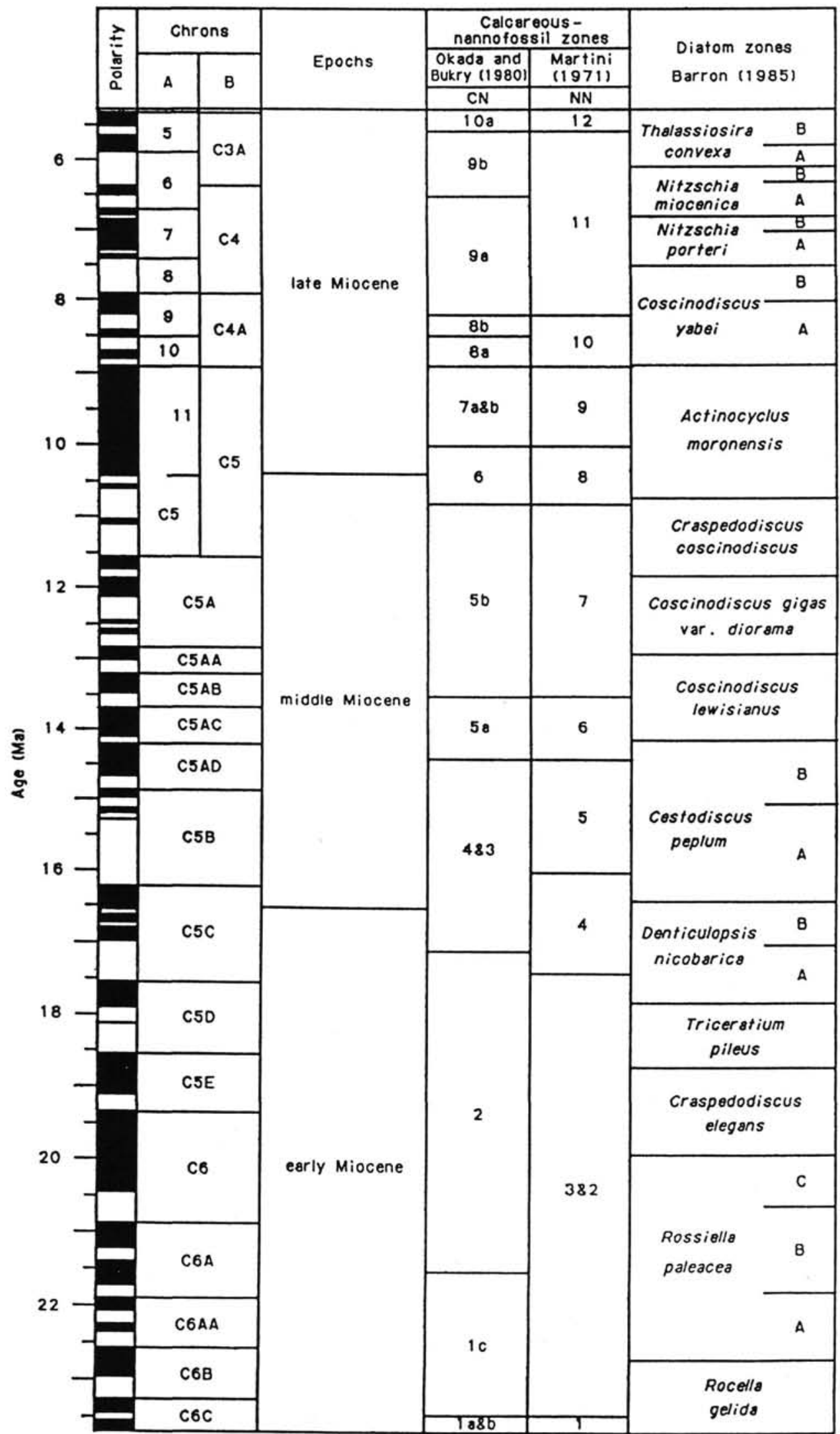

Figure 3. Miocene diatom zonation used during Leg 108. This zonation is a composite zonation of Burckle (1977), Barron (1985a), and Baldauf (1984, 1987). 


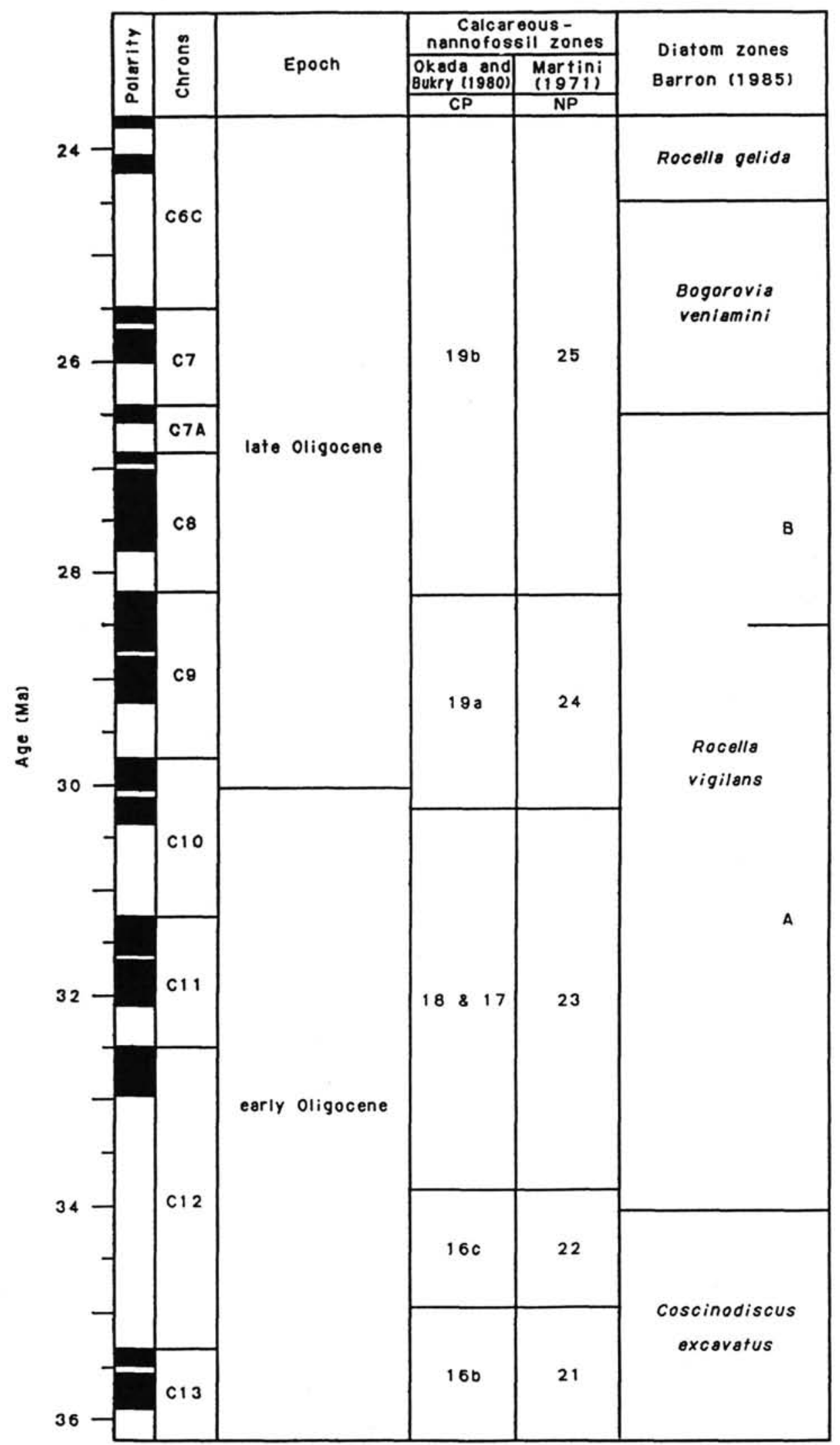

Figure 4. Oligocene diatom zonation used during Leg 108. This zonation is a composite zonation of Burckle (1977), Barron (1985a), and Baldauf (1984, 1987). 

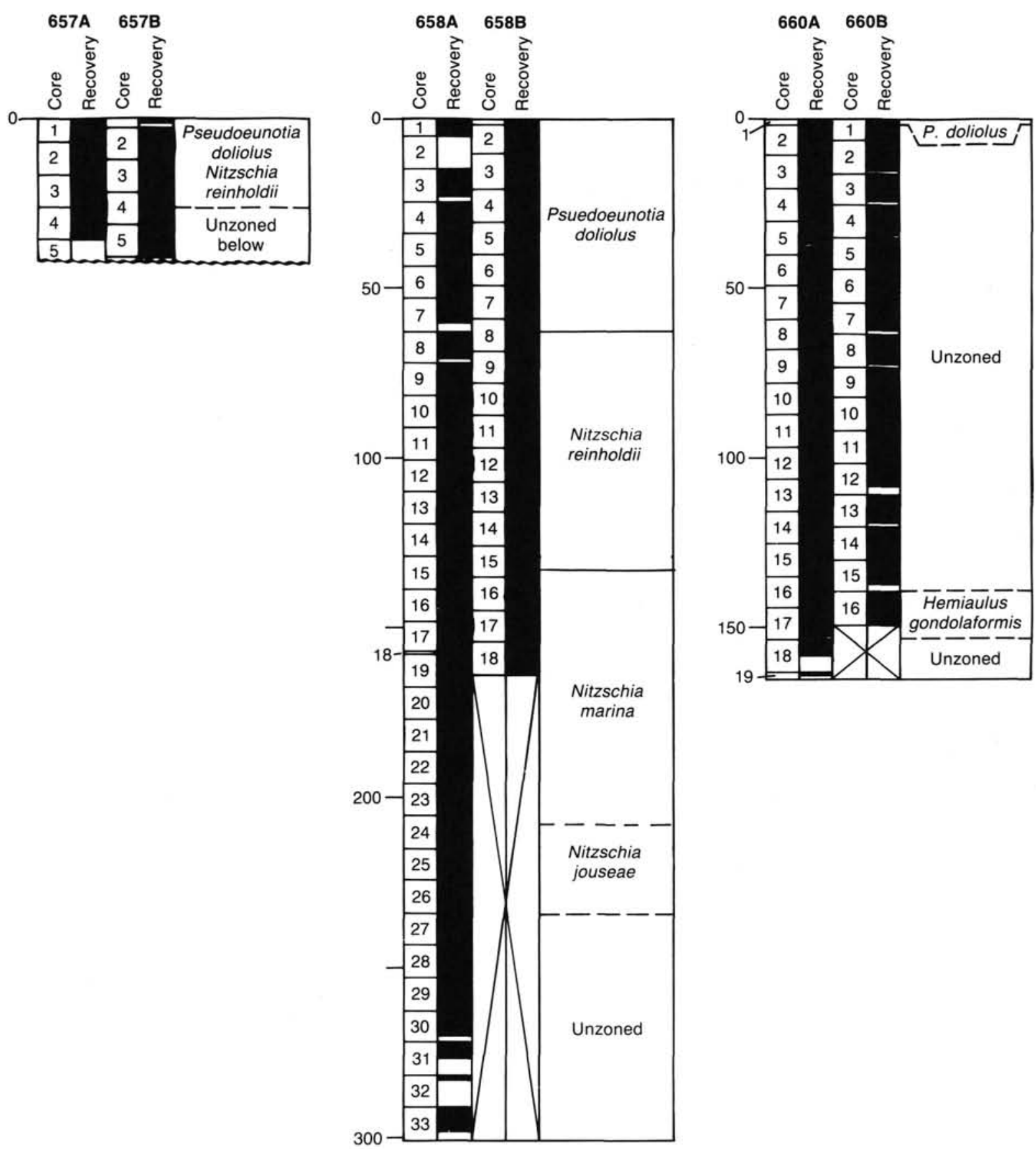

Figure 5. Diatom biostratigraphic results from Sites $657-658,660,662-665$, and $667-668$. The sparse occurrence of diatoms at Sites 661 and 666 prevents any reliable stratigraphic interpretations.

108-660B-2H through Sample 108-660B-13H-2, 42-44 cm, either contain rare diatom fragments or are barren of diatoms.

The occurrence of Triceratium schulzii and Triceratium brachiatum in Sample 108-660A-14H-2, 100-102 cm, suggests a middle Eocene age for this sample. Triceratium schulzii is recorded from middle Eocene sediments at DSDP Site 354 (Fenner, 1978), the middle Eocene of the Kellogg Shale (Barron et al., 1985), and the late Eocene of the Norwegian Sea (Schrader and Fenner, 1976). Triceratium brachiatum is recorded from middle Eocene sediments of DSDP Site 149 in the Caribbean Sea (Fenner, 1985). Other Paleogene species present in this sample include Pyxilla prolongata and Melosira architecturalis.
Rare to few diatoms generally exhibiting poor preservation occur in samples examined from Cores $108-660 \mathrm{~A}-15 \mathrm{H}$ through $-17 \mathrm{H}$ and Cores $108-660 \mathrm{~B}-15 \mathrm{H}$ and $-16 \mathrm{H}$. The sedimentary sequence representing these intervals are dominated by common to abundant fragments of radiolarians; the high degree of fragmentation suggests possible current transport of the sediment.

The occurrence of $T$. brachiatum and Triceratium inconspicuum in Sample 108-660A-16H-2, 85-87 cm, T. brachiatum in Sample 108-660A-15H-5, 42-44 cm, and Pyxilla caput avis in Samples 108-660A-15H-5, 42-44 cm, and 108-660A$16 \mathrm{H}-\mathrm{CC}$ suggest that this interval is equivalent to the middle Eocene Pyxilla caput avis through Hemiaulus gondolaformis 


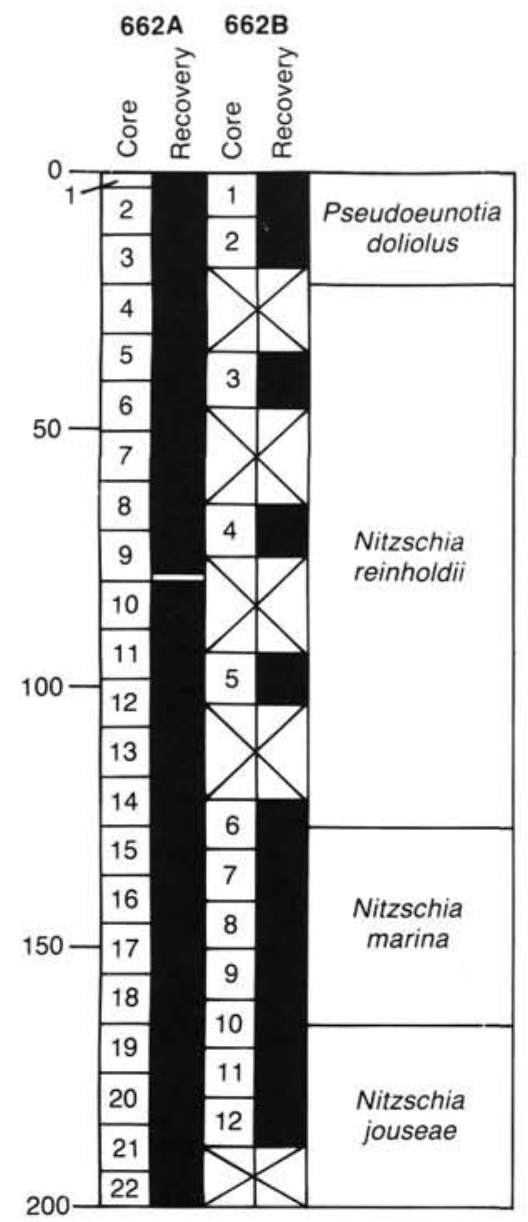

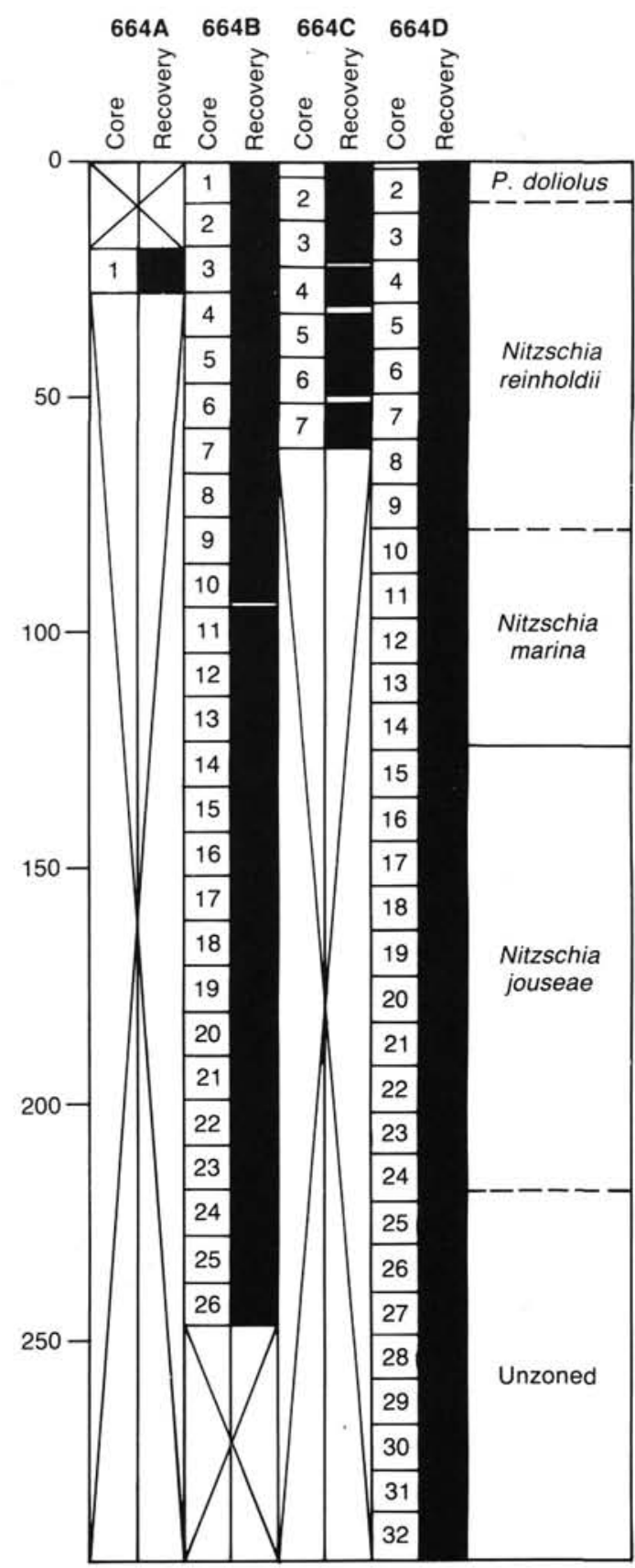

Figure 5 (continued).

Zones of Fenner (1985). The occurrence of Hemiaulus gondolaformis in Sample 108-660A-16H-CC allows placement of this sample into the $H$. gondolaformis Zone of Fenner (1984).

The occurrence of Triceratium cf. barbadense in samples from Cores $108-660 \mathrm{~A}-15 \mathrm{H}$ through $-17 \mathrm{H}$ and Cores 108 $660 \mathrm{~B}-14 \mathrm{H}$ through $-17 \mathrm{H}$ suggests a middle Eocene age for this interval. No age-diagnostic species were observed in samples examined from Core $108-660 \mathrm{~A}-18 \mathrm{H}$.

\section{SITE 661}

Site 661, situated east of Kane Gap (Table 1 and Fig. 1), is the second of a two-site transect (with Site 660) cored to document late Neogene bottom-current activity and deepwater stagnation. Holes $661 \mathrm{~A}$ and $661 \mathrm{~B}$ were cored to 296.1 and 81.7 mbsf, respectively.
Diatoms were generally absent from samples examined from Site 661. The occasional samples that contain diatoms have an assemblage composed of rare to few, poorly preserved specimens. Specimens observed are characteristic of pelagic, neritic, and freshwater environments. With the exception of rare fragments of Nitzschia jouseae, no agediagnostic species were observed. The occurrence of $N$. jouseae in Sample 108-661A-8H-2, 42-44 cm, allows tentative placement of this sample into the Nitzschia jouseae Zone of Baldauf (1984). Rare pyritized specimens of primitive forms of Triceratium sp., ?Coscinodiscus sp., and Hemiaulus sp. occur in Samples 108-661A-25X-CC and 108-661A-27X-CC. These samples are assigned a Cretaceous age based on the calcareous nannofossil biostratigraphy (Manivit, this vol.). 

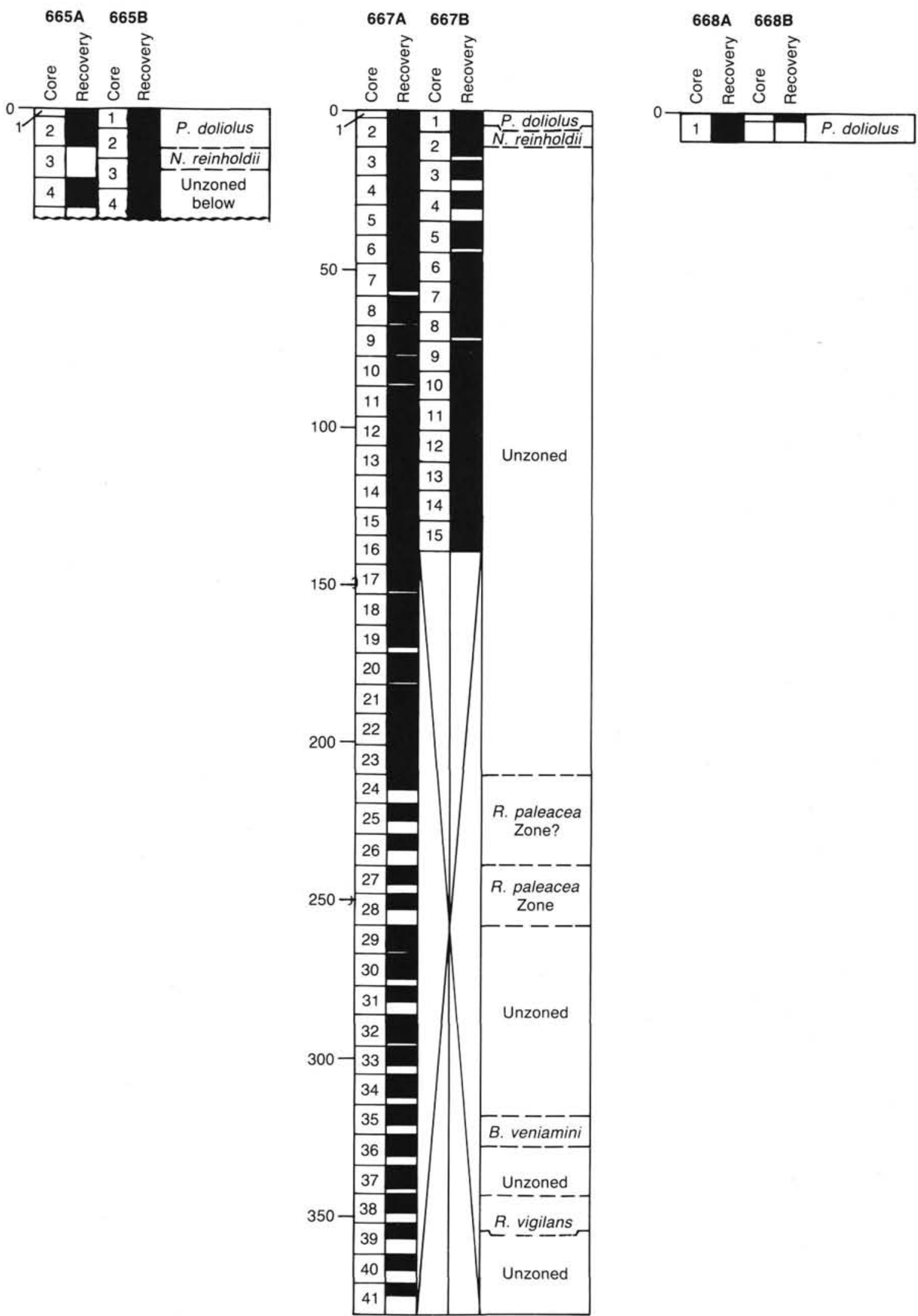

Figure 5 (continued). 


\section{SITE 662}

Site 662 was positioned on the eastern flank of the midAtlantic Ridge (Table 1 and Fig. 1) to obtain a Neogene record of equatorial divergence and eolian sedimentation. Holes $662 \mathrm{~A}$ and $662 \mathrm{~B}$ were drilled to depths of 188.2 and $200.0 \mathrm{mbsf}$, respectively.

Diatoms are generally common to abundant in the samples examined. Preservation is variable with the majority of samples containing a moderately well-preserved diatom assemblage. The diatom assemblage is dominated by transitional species indicative of moderate to high productivity. The species diversity and composition varies for each sample and may reflect surfacewater response to glacial and interglacial conditions. Samples dominated by $P$. doliolus, Thalassionema nitzschioides, and fragments of Ethmodiscus rex suggest glacial intervals, whereas samples dominated by Coscinodiscus nodulifer and Roperia tesselata were probably deposited during interglacial conditions. Windblown freshwater diatoms, predominantly Melosira spp., also occur in varying numbers.

Biostratigraphically useful Pliocene to Holocene species typical of the tropical regions are present at Site 662 . The occurrence of $P$. doliolus without $N$. reinholdii allows Cores 108-662A-1H through $-2 \mathrm{H}$ to be assigned to the Pseudoeunotia doliolus Zone of Burckle (1977). The LO of $N$. reinholdii in Sample 108-662A-3H-CC and the FO of $P$. doliolus in Sample 108-662A-15H-CC and 108-662B-7H-5, 42-44 cm, allows Cores $108-662 \mathrm{~A}-4 \mathrm{H}$ through $-15 \mathrm{H}$ to be placed in the Nitzschia reinholdii Zone. Similar to the findings of $\mathrm{L}$. H. Burckle and E. Fourtanier (pers. comm., 1984), P. doliolus appears in the equatorial Atlantic prior to its $\mathrm{FO}$ in the eastern equatorial Pacific or middle-latitude North Atlantic. At Site 662, the FO of $P$. doliolus has an estimated age between 2.1 and $2.2 \mathrm{Ma}$ compared with an age of $1.8 \mathrm{Ma}$ for this event in the equatorial Pacific (Barron, 1980) and the North Atlantic (Baldauf et al., 1987).

Cores 108-662A-15H through 108-662A-18H-5, $110 \mathrm{~cm}$, are assigned to the Nitzschia marina Zone based on the occurrence of $N$. marina between the LO of $N$. jouseae in Sample 108-662A-18H-5, $110 \mathrm{~cm}$, and the FO of $P$. doliolus in Sample 108-662A-15H-CC. The sporadic occurrence of $N$. jouseae in Samples 108-662A-18H-5, $110 \mathrm{~cm}$, through 108$662 \mathrm{~A}-22 \mathrm{H}$ allows samples from this interval to be placed into the Nitzschia jouseae Zone of Baldauf (1984).

\section{SITE 663}

Similar to Site 662 , Site 663 was positioned on the eastern flank of the mid-Atlantic Ridge (Table 1 and Fig. 1) in the eastern Atlantic to monitor the Neogene history of equatorial divergence and eolian deposition. Two holes (663A and 663B) were cored at this site: Hole $663 \mathrm{~A}$ penetrated $147.2 \mathrm{mbsf}$, and Hole 663B penetrated 150.0 mbsf.

The diatom assemblage observed at this site is similar to that observed at Site 662 and is characterized by species typical of a transitional, moderate to high surface-productivity environment. Few to abundant diatoms are present in all samples examined. Preservation is generally moderate with occasional samples exhibiting poor preservation. The diatom assemblage is typified by pelagic and freshwater (eolian) species.

Similar to Site 662 , diatom biostratigraphy allows recognition of the upper portion of the Nitzschia jouseae through the Pseudoeunotia doliolus Zones. Cores 108-663A-1H and -2H are assigned to the Pseudoeunotia doliolus Zone of Burckle (1977) based on the occurrence of $P$. doliolus without $N$. reinholdii. Although N. reinholdii occurs in Sample 108$663 \mathrm{~B}-1 \mathrm{H}-\mathrm{CC}$, it is assumed that the rare specimens observed are reworked.
The co-occurrence of $N$. reinholdii and $P$. doliolus in the interval from Sample 108-663A-3H-5, 42-44 cm, through Core $108-663 \mathrm{~A}-11 \mathrm{H}$ allows the samples to be assigned to the Nitzschia reinholdii Zone. The LO of $T$. convexa in Sample 108-663B-14H-CC and the last common occurrence of $N$. jouseae in Sample 108-663A-15H-CC allows Cores 108-663A$12 \mathrm{H}$ through the lowermost portion of Core $108-663 \mathrm{~A}-15 \mathrm{H}$ to be assigned to the Nitzschia marina Zone of Baldauf (1984). Cores $108-663 \mathrm{~A}-16 \mathrm{H}$ and $108-663 \mathrm{~B}-16 \mathrm{H}$ are assigned to the Nitzschia jouseae Zone. The placement of the top of this zonal boundary is tentative since rare specimens of $N$. jouseae are observed occasionally throughout Cores $108-663 \mathrm{~A}-11 \mathrm{H}$ through $-14 \mathrm{H}$; these specimens are assumed to be reworked.

\section{SITE 664}

Site 664 is situated on the mid-Atlantic ridge just north of the Romanche Fracture Zone (Table 1 and Fig. 1). The scientific objectives at this site are similar to those at Sites 662 and 663 . Four holes were cored at this site. Hole $664 \mathrm{~A}$ consisted of a single core from a depth of 28.9 mbsf. Holes 664B through 664D penetrated $247.0,61.2$, and $296.8 \mathrm{mbsf}$, respectively.

Similar to Sites 662 and 663 , diatoms are observed only in the upper Pliocene and Quaternary sediments. Diatom abundance and preservation vary from sample to sample but, in general, both are lower than at Sites 662 and 663 .

The presence of $P$. doliolus without $N$. reinholdii in samples from Cores 108-664C-1H and $-2 \mathrm{H}$ and 108-664D-1H allows these intervals to be placed into the Pseudoeunotia doliolus Zone. Both $N$. reinholdii and $P$. doliolus were observed in Sample 108-664A-1H-CC, Cores 108-664B-1H through $-5 \mathrm{H}$, Samples 108-664C-3H-CC through 108-664C$7 \mathrm{H}-\mathrm{CC}$, and Samples 108-664D-3H-CC through 108-664D$10 \mathrm{H}-\mathrm{CC}$. Thus, these intervals are assigned to the Nitzschia reinholdii Zone. The FO of $P$. doliolus in Sample 108$664 \mathrm{D}-9 \mathrm{H}-\mathrm{CC}$ marks the base of the Nitzschia reinholdii Zone. Because of the occurrence of slump deposits and/or a decline in the diatom preservation and abundance, this zonal boundary was not recognized in Hole 664B.

The LO of N. jouseae in Samples 108-664B-14H-CC and 108-664D-14H allows the interval between Samples 108$664 \mathrm{D}-10 \mathrm{H}-\mathrm{CC}$ through 108-664D-13H-CC to be placed into the Nitzschia marina Zone. Specimens of $N$. jouseae occur downsection until Cores 108-664C-23H and 108-664D-17H, suggesting that these intervals are equivalent to the Nitzschia jouseae Zone. The base of this zone was not recognized, since the abundance and preservation of diatoms abruptly decline below Core 108-664D-20H. This sharp downhole decline in the preservation of biosiliceous material suggests that the equatorial divergence at Site 664 may have been less intense prior to $3.5 \mathrm{Ma}$.

\section{SITE 665}

Sites 665 through 668 (Table 1 and Fig. 1) were positioned on the Sierra Leone Rise to monitor late Neogene, long-term fluxes in calcium carbonate and calcium carbonate dissolution. Site 665 is located on the southwest margin of this rise. Holes $665 \mathrm{~A}$ and 665B penetrated 97.9 and 71.7 mbsf, respectively.

Diatoms were only observed in a few samples. The assemblage present is composed of pelagic species, freshwater (eolian) species, and fragments of Ethmodiscus sp. With the exception of the uppermost sequence, age-diagnostic species were not observed. The occurrence of $P$. doliolus without $N$. reinholdii in samples examined from the first two cores of Hole 665B allows these cores to be assigned to the Pseudoeunotia doliolus Zone. The co-occurrence of these species in Sample 108-665A-2H-CC places this sample in the Nitzschia reinholdii zone. 


\section{SITE 666}

Site 666 is an intermediate member of the Sierra Leone Rise transect. Because of extensive turbidite deposits, only one hole (666A) was cored at this site to a depth of $150.0 \mathrm{mbsf}$. Rare diatoms occur sporadically in the upper portion of Hole 666A. Species present include specimens of freshwater Melosira, the marine species Coscinodiscus marginatus, and fragments of Ethmodiscus sp. No age-diagnostic species were observed.

\section{SITE 667}

Site 667 , also an intermediate member of the Sierra Leone Rise transect, is positioned on the western margin of the Sierra Leone Rise (Table 1 and Fig. 1) to monitor Neogene deep-water circulation. Hole $667 \mathrm{~A}$ recovered 41 cores that penetrated $381.3 \mathrm{mbsf}$, and Hole $667 \mathrm{~B}$ recovered 15 cores to a depth of 139.1 mbsf.

Diatoms are generally absent in the samples examined. However, poor to well-preserved and few to common species were observed in Cores $108-667 \mathrm{~A}-1 \mathrm{H},-2 \mathrm{H},-23 \mathrm{H}$ through $-31 \mathrm{X}$, and $-33 \mathrm{X}$ to $-39 \mathrm{X}$ as well as in Core $108-667 \mathrm{~B}-1 \mathrm{H}$. These intervals are Pleistocene-Holocene and Oligocene-early Miocene in age.

The Nitzschia reinholdii/Pseudoeunotia doliolus zonal boundary is placed between Samples 108-667A-1H-CC and 108-667A-2H-CC based on the sole occurrence of $P$. doliolus in Core 108-667A-1H and the co-occurrence of $P$. doliolus and N. reinholdii in Sample 108-667A-2H-CC. Diatoms were generally not observed from samples in the interval from Cores $108-667 \mathrm{~A}-3 \mathrm{H}$ through $-22 \mathrm{H}$.

The diatoms present in Cores 108-667A-23H through -31X and 108-667A-33X through $-39 \mathrm{X}$ are similar to those described by Barron (1985a) from the equatorial Pacific. The interval from Sample 108-667A-24X-6, 20-22 cm, through Core 108667A-26X is tentatively assigned to the early Miocene Rossiella paleacea Zone based on the sporadic occurrence of Coscinodiscus oligocenicus, Synedra jouseana, and Craspedodiscus elegans in this interval.

Samples 108-667A-27X-CC and 108-667A-28X-CC are assigned to the upper portion of Subzone A of the Rossiella paleacea Zone based on the co-occurrence of Bogorovia veniamini, Thalassiosira primalabiata, and Rossiella paleacea. The occurrence of $B$. veniamini, Coscinodiscus lewisianus var. similis, S. jouseana, and Rocella vigilans without $R$. paleacea and Rocella gelida in Sample 108-667A-35X-4, $10-12 \mathrm{~cm}$, suggests placement of this sample into the Bogorovia veniamini Zone.

Sample 108-667A-38X-CC is tentatively placed in Subzone A of the Rocella vigilans Zone based on the occurrence of common $R$. vigilans and rare specimens of Cestodiscus muhinae.

\section{SITE 668}

Site 668 was drilled on the crest of the Sierra Leone Rise as a companion site to Sites 665 through 667 (Table 1 and Fig. 1). The primary objective at this site was to recover a continuous upper Neogene section to monitor deep-water circulation in the eastern equatorial Atlantic.

Rare diatoms were observed in the few samples examined from this site. Preservation is generally poor and, with the exception of the occurrence of $P$. doliolus in samples from Core 108-668A-1H and Sample 108-668B-1H-CC, age-diagnostic species were not observed. The occurrence of $P$. doliolus without $N$. reinholdii allows these intervals to be placed into the Pseudoeunotia doliolus Zone.

\section{DISCUSSION}

Figure 5 shows diatom biostratigraphic results from Leg 108. Sites 659 and 666 are excluded from this diagram because diatoms were generally absent from the samples examined. As a rule, diatom abundances and preservation in the PliocenePleistocene are greater at sites underlying surface waters that today are relatively rich in nutrients and exhibit moderate to high surface-water productivity.

The existence of a permanent cell of upwelling off northwest Africa thus explains why diatom assemblages are richer at Site 658 than at nearby Sites 657 and 659, which lie outside the upwelling cell. Similarly, the strong divergence along the equator, together with advection of nutrient-rich waters in the Benguela Current, leads to the high productivity of equatorial waters and, hence, to the relatively rich diatom assemblages at Sites 662,663 , and 664 . The fact that diatoms tend to be more abundant and better preserved at Sites 662 and 663 than at Site 664 is consistent with the east-to-west decrease in nutrient contents and productivity levels of equatorial waters. Leg 108 sites on and near the Sierra Leone Rise (Sites 660, 661 , and 665-668) are also under waters of relatively low productivity and therefore are poor in diatoms.

Comparing Pliocene and Quaternary sediments from each of these sites shows that biosiliceous sediments (based on diatom presence and absence) occurs during the interval equivalent to the upper portion of the Nitzschia jouseae Zone to the present day. Thus, siliceous deposition similar to the present day has occurred in these regions during the latest early Pliocene (about $3.5 \mathrm{Ma}$ ) to the present. Prior to this time (late Miocene and early Pliocene), biosiliceous sediments (diatoms) do not occur at these sites. The transition from siliceous to nonsiliceous sediments at about 3.5 Ma suggests that present-day surface circulation patterns were established at this time (i.e., equatorial divergence and upwelling), increasing both surface productivity and the flux of biogenic silica to the seafloor.

\section{CONCLUSION}

Siliceous microfossils, specifically diatoms, are useful as general stratigraphic indicators for the middle Eocene, upper Oligocene-lower Miocene, and upper Pliocene-Holocene sediments recovered during Leg 108 in the eastern Atlantic. Based on diatom biostratigraphy, the stratigraphic intervals containing a siliceous component can be placed into the Hemiaulus gondolaformis, Bogorovia veniamini, Rossiella paleacea, and the upper portion of the Nitzschia jouseae through Pseudoeunotia doliolus Zones.

The stratigraphic markers used to define the Pliocene through Holocene zones are calibrated to magnetostratigraphy in both the equatorial Pacific (Burckle, 1977; Barron, 1985a) and in the middle and high latitudes of the North Atlantic (Baldauf, 1987; Baldauf et al., 1987). Comparisons of the stratigraphic ranges of marker species in the Leg 108 sediment suggest that the species in the eastern tropical Atlantic have stratigraphic ranges similar to those in the middle- and high-latitude North Atlantic rather than to those in the eastern equatorial Pacific.

The diatom assemblage present in Leg 108 sediments consists of pelagic species typical of the low latitudes, pelagic species characteristic of moderate to high surface-water productivity, freshwater species indicative of eolian deposition, and occasional nearshore benthic forms.

Examination of the Pliocene and Quaternary sequences recovered from the 11 sites occupied during Leg 108 indicates that, if present, biosiliceous sediments were generally incor- 
porated into the sediment record during the time equivalent to and younger than the upper portion of the Nitzschia jouseae Zone (latest early Pliocene; about 3.5 Ma). This suggests that the present-day pattern of surface productivity in response to equatorial surface circulation (divergence) commenced about that time.

\section{ACKNOWLEDGMENTS}

We thank Doris Cooley, Amy Russell, and Judy Duke for typing, and Chris Yokley, Garnet Gaither, and Peggy Myre for drafting. Financial support for this study was received from USSAC (J. G. Baldauf) and from the National Science Foundation grant OCE8700505 (E. M. Pokras).

\section{REFERENCES}

Baldauf, J. G., 1984. Cenozoic diatom biostratigraphy and paleoceanography of the Rockall Plateau Region, North Atlantic, Deep Sea Drilling Project Leg 81. In Roberts, D., Schnitker, D., et al., Init. Repts. DSDP, 81: Washington (U.S. Govt. Printing Office), 439-478. 1985. A high resolution late Miocene-Pliocene diatom biostratigraphy for the eastern equatorial Pacific. In Mayer, L., Theyer, F., et al., Init. Repts. DSDP, 85: Washington (U.S. Govt. Printing Office), 457-475.

1986. Diatom biostratigraphic and paleoceanographic interpretations for the middle to high latitude North Atlantic Ocean. In Summerhayes, C., and Shackleton, N. J. (Eds.), North Atlantic Paleoceanography: London (Blackwell Scientific), 243-254. 1987. Diatom biostratigraphy of the middle- and high-latitude North Atlantic Ocean, Deep Sea Drilling Project Leg 94. In Ruddiman, W. F., Kidd, R. B., Thomas, E., et al., Init. Repts. DSDP, 94, Pt. 2: Washington (U.S. Govt. Printing Office), 729-762.

Baldauf, J. G., Thomas, E., Clement, B., Takayama, T., Weaver, P.P.E., Backman, J., Jenkins, G., Mudie, P. J., and WestbergSmith, M. J., 1987. Magnetostratigraphic and biostratigraphic synthesis, Deep Sea Drilling Project Leg 94. In Ruddiman, W. F., Kidd, R. B., Thomas, E., et al., Init. Repts. DSDP, 94, Pt. 2: Washington (U.S. Govt. Printing Office), 1159-1205.

Barron, J. A., 1980. Upper Pliocene and Quaternary diatom biostratigraphy of the Deep Sea Drilling Project Leg 54, tropical eastern Pacific. In Rosendahl, B. R., Hekinian, R., et al., Init. Repts. DSDP, 54: Washington (U.S. Govt. Printing Office), 455-485.

1983. Latest Oligocene through early middle Miocene diatom biostratigraphy of the eastern tropical Pacific. Mar. Micropaleontol., 7:487-515.

1985a. Late Eocene to Holocene diatom biostratigraphy of the equatorial Pacific Ocean, Deep Sea Drilling Project Leg 85. In Mayer, L., Theyer, F., et al., Init. Repts. DSDP, 85: Washington (U.S. Govt. Printing Office), 413-456.

1985b. Miocene to Holocene planktic diatoms. In Bolli, H. M., Saunders, J. B., and Perch-Nielsen, K. (Eds.), Plankton Stratigraphy: Cambridge (Cambridge Univ. Press), 763-809.

Barron, J. A., Nigrini, C. A., Pujos, A., Saito, T., Theyer, F., Thomas, E., and Weinreich, N., 1985. Synthesis of biostratigraphy, central equatorial Pacific, Deep Sea Drilling Project Leg 85: refinement of Oligocene to Quaternary biochronology. In Mayer, L., Theyer, F., et al., Init. Repts. DSDP, 85: Washington (U.S. Govt. Printing Office), 905-933.

Berggren, W. A., Kent, D. V., and Flynn, J. J., 1985a. Jurassic to Paleogene: Part 2, Paleogene geochronology and chronostratigraphy. In Snelling, N. J. (Ed.), The Chronology of the Geological Record. Geol. Soc. Mem. (London), 10:141-195.

Berggren, W. A., Kent, D. V., and Van Couvering, J. A., 1985b. The Neogene: Part 2, Neogene geochronology and chronostratigraphy. In Snelling, N. J. (Ed.), The Chronology of the Geological Record. Geol. Soc. Mem. (London), 10:211-260.

Burckle, L. H., 1972. Late Cenozoic planktonic diatom zones from the eastern equatorial Pacific. Nova Hedwigia, Beih., 39:217-250. 1977. Pliocene and Pleistocene diatom datum levels from the equatorial Pacific. Quat. Geol., 7:330-340. 1978. Early Miocene to Pliocene diatom datum levels for the equatorial Pacific. Bull. Geol. Res. Dev. Cent. (Bandung, Indones.), Spec. Publ., 1:25-44.

Burckle, L. H., and Opdyke, N. D., 1977. Late Neogene diatom correlations in the circum-Pacific. Proc. First Int. Congr. Pacific Neogene Stratigr. (Tokyo, 1976): Tokyo (Kaiyo Shuppan Co., Ltd.), 255-284.

Burckle, L. H., and Trainer, J., 1979. Middle and late Pliocene diatom datum levels from the central Pacific. Micropaleontology, 25:281-293.

Fenner, J., 1978. Cenozoic diatom biostratigraphy of the equatorial and southern Atlantic Ocean. In Talwani, M., Udintsev, G., et al., Init. Repts. DSDP, Suppl. to $38,39,40$, and 41 : Washington (U.S. Govt. Printing Office), 491-624.

1984. Eocene-Oligocene planktic diatom stratigraphy in the low latitudes and the high southern latitudes. Micropaleontology, 30:319-342.

1985. Late Cretaceous to Oligocene planktic diatoms. In Bolli, H. M., Saunders, J. B., and Perch-Nielsen, K. (Eds.), Plankton Stratigraphy: Cambridge (Cambridge Univ. Press), $713-762$.

Harwood, D. M., 1982. Oligocene-Miocene diatom biostratigraphy from the equatorial to the antarctic Pacific [Master's thesis]. Florida State Univ., Tallahassee.

Sancetta, C. A., 1983. Biostratigraphic and paleoceanographic events in the eastern equatorial Pacific: results of Deep Sea Drilling Project Leg 69. In Cann, J. R., et al., Init. Repts. DSDP, 69: Washington (U.S. Govt. Printing Office), 311-342.

Schrader, H. J., 1977. Diatom biostratigraphy, Deep Sea Drilling Project Leg 37. In Aumento, F., Melson, W. G., et al., Init. Repts. DSDP, 37: Washington (U.S. Govt. Printing Office), 967-975.

Schrader, H. J., and Fenner, J., 1976. Norwegian Sea Cenozoic diatom biostratigraphy and taxonomy. In Talwani, M., Udintsev, G., et al., Init. Repts. DSDP, 38: Washington (U.S. Govt. Printing Office), 921-1099.

Schrader, H. J., and Gersonde, R., 1978. Diatoms and silicoflagellates. Utrecht Micropaleontol., 17:129-176.

Date of initial receipt: 10 March 1988

Date of acceptance: 12 February 1989

Ms 108B-123 